\title{
OS AUTOS QUE CRESCEM E O PATRIMÔNIO CULTURAL QUE PADECE: A CIDADE PATRIMÔNIO E A JUDICIALIZAÇÃO
}

\section{THE PROCESSES ARE INCREASING AND THE CULTURAL HERITAGE IS SUFFERING: THE CITY HERITAGE AND THE THE INSTITUTIONS OF THE FEDERAL JUSTICE SYSTEM}

\author{
José Odval Alcântara Júnior ${ }^{1}$ \\ Mônica Teresa Costa Sousa ${ }^{2}$ \\ Paulo Fernando Soares Pereira ${ }^{3}$
}

\begin{abstract}
Resumo
O trabalho aborda a efetividade da judicialização envolvendo a tutela do patrimônio cultural imobiliário, na Zona de Tombamento Federal, na cidade de São Luís, detentora do título de "Patrimônio Cultural da Humanidade", concedido pela UNESCO, em 1997, em função da singularidade e harmonia de seu acervo arquitetônico, como já havia reconhecido o Instituto do Patrimônio Histórico e Artístico Nacional - IPHAN, em 1974. A problemática, portanto, consiste em indagar a razão pela qual as Instituições do Sistema de Justiça Federal não conseguem dar efetividade ao comando constitucional de tutela do patrimônio cultural.
\end{abstract}

Palavras-chave: Patrimônio Cultural. Proteção. Sistema de Justiça. Sociedade civil. Diálogo.

\section{Abstract}

The essay approaches the effectiveness of judicialisation involving the safeguard of protected real estate cultural heritage area, in São Luís, honored as Cultural Heritage of Humanity by UNESCO in 1997, due to its unique and harmonic architectural acquis, also recognized by IPHAN (abbreviation in Portuguese for National Institute for Historical and Artistic Heritage), in 1974. The issue consists in questioning the reason why the Federal Justice System cannot bring effectiveness to the constitutional commands for cultural heritage protection.

Keywords: Cultural heritage. Protection. Justice System. Civil society. Dialogue.

\footnotetext{
${ }^{1}$ Docente da Graduação e do Programa de Pós-Graduação em Ciências Sociais (UFMA). Pós-doutorado na Universidade de São Paulo (USP). Coordenador do Grupo de Estudos e Pesquisas das Formas Sociais. E-mail: josealcantarajr@uol.com.br

2 Docente do Programa de Pós-Graduação em Direito e Instituições do Sistema de Justiça (UFMA). Doutora em Direito pela Universidade Federal de Santa Catarina - UFSC. Avaliadora do MEC/INEP. Coordenadora do Núcleo de Estudos em Direito e Desenvolvimento e do Núcleo de Assessoria Jurídica Popular (NAJUP) "Negro Cosme". E-mail: mtcostasousa@uol.com.br

3 Doutorando em Direito, Constituição e Democracia pela Universidade de Brasília - UnB. Membro da Advocacia-Geral da União (Procurador Federal com exercício no Estado do Maranhão). E-mail: paulo.soares@agu.gov.br
} 


\section{INTRODUÇÃO}

A partir da análise de dados contidos em processos judiciais, o trabalho pretende discutir a efetividade da judicialização envolvendo a tutela do patrimônio cultural imobiliário, na Zona de Tombamento Federal, na cidade de São Luís, detentora do título de "Patrimônio Cultural da Humanidade", concedido pela UNESCO, em 1997, em função da singularidade e harmonia de seu acervo arquitetônico, como já havia reconhecido o Instituto do Patrimônio Histórico e Artístico Nacional - IPHAN, em 1974.

A problemática, portanto, consiste em indagar a razão pela qual as Instituições do Sistema de Justiça Federal não conseguem dar efetividade ao comando constitucional de tutela do patrimônio cultural. Para tanto, o trabalho elenca 03 (três) fatores que contribuem para essa falta de efetividade: a) a questão da pobreza; b) a falta de estímulos à diversidade urbana e; c) a inexistência de um diálogo com a sociedade civil.

Assim, o trabalho inicia apresentando o contexto da modernização das cidades em países de capitalismo periférico, como é o caso de São Luís, em que a modernização pode ser entendida como um esforço de atualização e uma forma de medir a suposta evolução das sociedades centrais (ARANTES, 2001). Essa busca pela modernização da cidade foi acompanhada de diversos equívocos, que, atualmente, comprometem a execução das políticas de proteção ao patrimônio cultural da cidade.

O primeiro equívoco é desconsiderar o fator pobreza. O que leva um Centro Histórico a ser deixado ao abandono, como se a cidade antiga já não atendesse aos novos anseios de uma cidade seduzida pelo concreto, pelo vidro e outros padrões de consumo emergentes?

Prosseguindo com as discussões, apresenta-se um segundo equívoco/obstáculo causado pela falta de estímulos à diversidade urbana que a cidade vem enfrentando. Sobre essa temática, o trabalho vai tentar buscar respostas em Jane Jacobs (2000).

Para finalizar, como terceiro equívoco, discorre-se a respeito da inexistência de um diálogo com a sociedade civil, que é mero receptáculo daquilo que é inventado pela tecnocracia como sendo o patrimônio a ser preservado, sendo este um dos pontos mais problemáticos das políticas patrimoniais aplicadas ao Centro Histórico de São Luís.

A metodologia foi dividida em dois eixos: o da pesquisa bibliográfica e o da pesquisa empírica. A pesquisa bibliográfica, com caráter interdisciplinar se baseou em referências teóricas da Sociologia e do Direito. Já a pesquisa empírica, documental, por amostragem, foi restrita, 
focando apenas as ações contra particulares que tiveram/têm como objetivo resguardar o patrimônio cultural imobiliário na Zona de Tombamento Federal - ZTF do Centro Histórico de São Luís (ações em curso na Seção Judiciária do Maranhão).

\section{A BUSCA PELA MODERNIZAÇÃO DA CIDADE, AS POLÍTICAS PATRIMONIAIS E A JUDICIALIZAÇÃO}

Em um país dependente e de capitalismo periférico, como é o Brasil, o que é considerado moderno pode se tornar uma obsessão nacional, já que a modernização pode ser entendida como um esforço de atualização e uma forma de medir a suposta evolução das sociedades centrais (ARANTES, 2001).

Assim, a busca pela modernidade, não só no plano industrial, econômico, cultural etc., deuse, também, no plano urbanístico, ocorrendo com certo atraso em algumas cidades. Não se pode desconsiderar que boa parte das ideias que permeiam a questão patrimonial advém do Congresso Internacional de Arquitetura Moderna (CIAM - Congress of International Modern Architects), que se reuniu em 1933, para elaborar um documento que definiria amplamente o objeto da prática arquitetônica moderna, a Carta de Atenas, que propôs que se conservassem unicamente os monumentos que oferecessem algum valor testemunhal do passado (HARVEY, 1989; LOURÉS SEOANE, 2001). Não custa transcrever a Carta naquilo que trata a respeito do que até então se denominava como "patrimônio histórico" que, hoje, recebe a terminologia mais abrangente "patrimônio cultural":

Patrimônio Histórico das Cidades

Os valores arquitetônicos devem ser salvaguardados (edifícios isolados ou conjuntos urbanos).

A vida de uma cidade é um acontecimento contínuo, que se manifesta ao longo dos séculos por obras materiais, traçados ou construções que the conferem sua personalidade própria e dos quais emana pouco a pouco a sua alma. São testemunhos preciosos do passado que serão respeitados, a princípio por seu valor histórico ou sentimental, depois, porque alguns trazem uma virtude plástica na qual se incorporou o mais alto grau de intensidade do gênio humano. Eles fazem parte do patrimônio humano, e aqueles que o detêm ou são encarregados de sua proteção, têm a responsabilidade e a obrigação de fazer tudo o que é lícito para transmitir intacta para os séculos futuros essa nobre herança.

Serão salvaguardados se constituem a expressão de uma cultura anterior e se correspondem a um interesse geral...

A morte, que não poupa nenhum ser vivo, atinge também as obras dos homens. É necessário saber reconhecer e discriminar nos testemunhos do passado aquelas que ainda estão bem vivas. Nem tudo que é passado tem, 
por definição, direito à perenidade; convém escolher com sabedoria o que deve ser respeitado. Se os interesses da cidade são lesados pela persistência de determinadas presenças insignes, majestosas, de uma era já encerrada, será procurada a solução capaz de conciliar dois pontos de vistas opostos: nos casos em que se esteja diante de construções repetidas em numerosos exemplares, algumas serão conservadas a título de documentário, as outras demolidas; em outros casos poderá ser isolada a única parte que constitua uma lembrança ou um valor real; o resto será modificado de maneira útil. Enfim, em certos excepcionais, poderá ser aventada a transplantação de elementos incômodos por sua situação, mas que merecem ser conservados por seu alto significado estético ou histórico. [...]

Os vestígios do passado mergulharão em uma ambiência nova, inesperada talvez, mas certamente tolerável, e da qual, em todo caso, os bairros vizinhos se beneficiarão amplamente.

O emprego de estilos do passado, sob pretextos estéticos, nas construções novas erigidas nas zonas históricas, têm consequências nefastas. A manutenção de tais usos ou a introdução de tais iniciativas não serão toleradas de forma alguma.

Tais métodos são contrários à grande lição da história. Nunca foi constatado um retrocesso, nunca o homem voltou sobre seus passos. As obras-primas do passado nos mostram que cada geração teve sua maneira de pensar, suas concepções, sua estética, recorrendo, como trampolim para sua imaginação, à totalidade de recursos técnicos de sua época. Copiar servilmente o passado é condenar-se à mentira, é erigir o "falso" como princípio, pois as antigas condições de trabalho não poderiam ser reconstituídas e a aplicação da técnica moderna a um ideal ultrapassado sempre leva a um simulacro desprovido de qualquer vida. Misturando o "falso" ao "verdadeiro", longe de se alcançar uma impressão de conjunto e dar a sensação de pureza de estilo, chega-se somente a uma reconstituição fictícia, capaz apenas de desacreditar os testemunhos autênticos, que mais se tinha empenho em preservar.

As concepções urbanistas traçadas pela Carta de Atenas, não sem um viés de dominação dos urbanistas e arquitetos nos campos de suas expertises, acabaram repercutindo pelo mundo afora, chegando ao Brasil, não sem certo atraso, e influenciando a legislação que tratava das formas urbanas e da proteção do patrimônio cultural.

Muitas cidades quiseram praticar verdadeira higienização urbana, demolindo as formas antigas; outras, não conseguindo extirpar o passado urbanístico, mesclaram as novas concepções em meio ao que já era considerado passado, enquanto algumas preferiram abandonar os velhos centros e se transportaram para bairros novos, supostamente em sintonia com os ecos de Atenas e na ilusão de imaginar que o desenvolvimento significaria apenas a simples ostentação de riqueza. Sobre esse movimento de modernização urbana, Otília Arantes (2001, p. 30-31) ensina que:

Modernizar-se - dos hábitos de consumo até os sentimentos estéticos - era condição de formação nacional, redenção do passado colonial etc. Dependendo do setor da vida nacional, combinou-se de modo variado o impulso do influxo externo e a persistência da resistência local, fonte perene 
de desajustes ou adaptações inesperadas. Foi o caso do Modernismo artístico, como é sabido - a estética antiburguesa que o definia na Europa viu-se confirmada pela atualidade do primitivismo brasileiro. Do episódio saía reforçada a mitologia do país novo condenado ao moderno. E assim por diante.

Em São Luís, não diferente de outros lugares, a modernização também foi buscada o que trouxe uma série de novas condutas envolvendo o modo de viver das pessoas, inclusive mudança de hábitos de habitação, em que a população passou a deixar o Centro Histórico em busca de outros espaços, supostamente mais condizentes com os novos padrões de urbanização.

Apesar de certo atraso em seu modernismo arquitetônico, a capital maranhense, a partir de 1950, buscou se inserir na lógica da Carta de Atenas; foram inseridos dentro do conjunto tombado alguns edifícios modernistas para abrigar órgãos públicos (LOPES, 2008; LACROIX, 2012) e outros fins, havendo diversos exemplos nesse sentido: o Edifício SULACAP (Rua de Nazaré, 19471950), Edifício João Goulart, antiga sede do INSS (Av. Pedro II, 1957), a sede do antigo Banco do Estado do Maranhão - BEM (Rua do Egito, início da década de 1970), o Edifício Caiçara (Rua Grande, início da década de 1970), Edifício São Marcos (Av. Getúlio Vargas, início da década de 1970), Edifício Colonial (Rua do Sol, 1977), Edifício Sede dos Órgãos Fazendários (Canto da Fabril, 1979). Além do mais, a construção das Pontes do São Francisco, batizada de Ponte José Sarney, em 1971, e Bandeira Tribuzi, em 1980, deram impulso à evasão do Centro Histórico para novos bairros.

Figura 1 - Edifício João Goulart, construído no Centro Histórico e, atualmente, objeto de judicialização

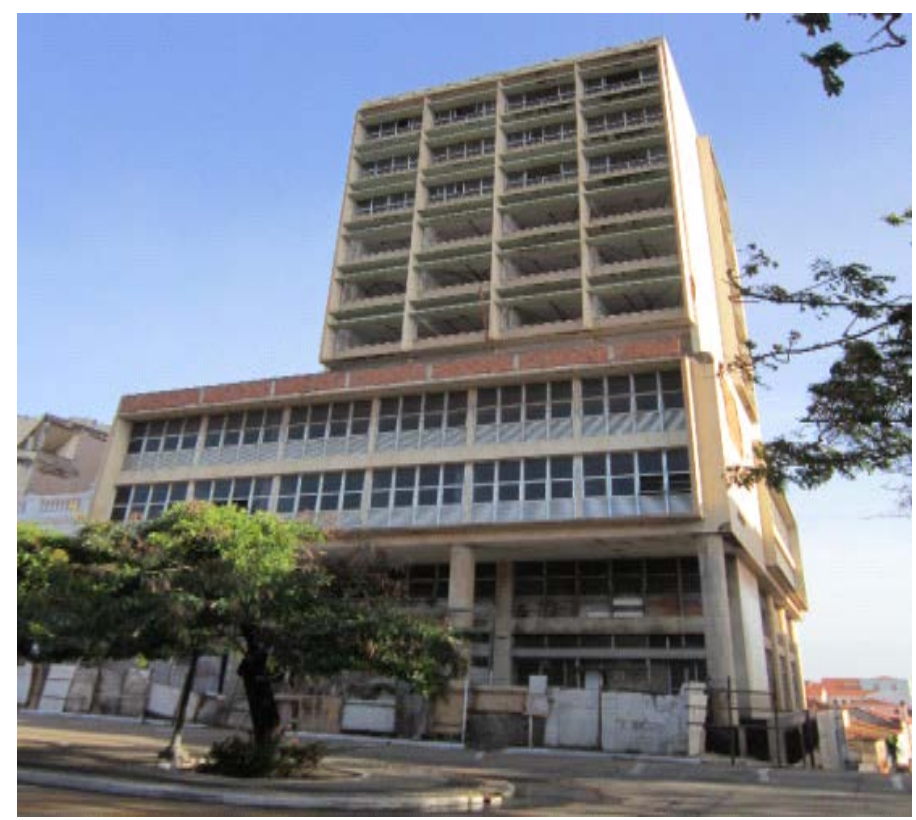

Fonte: arquivo pessoal 
A cidade cresceu e, consequentemente, novos problemas surgiram, inclusive o de lidar com a situação de seu Centro Histórico. Como conciliar o passado com as necessidades do presente e ainda se planejar o futuro urbano?

No ano de 2015, segundo o IBGE, São Luís, excluída a população dos Municípios da Região Metropolitana, possuía uma população estimada em 1.073 .893 (um milhão setenta e três mil e oitocentos e noventa e três habitantes), podendo ser considerada uma grande cidade, seja por sua população ou por seu espaço urbano $\left(834,785 \mathrm{~km}^{2}\right)$, encarando o problema de lidar com os conflitos de diversidade que os grandes centros enfrentam.

Nesse sentido, Jane Jacobs (2000) alerta que as metrópoles são geradoras naturais de diversidade e produtoras de novos empreendimentos e de todas as espécies de ideias; quanto maior a cidade, maior a variedade de seus produtos, sendo, igualmente, maior o número e a proporção de pequenos fabricantes, sendo essencial que a própria diversidade urbana seja estimulada.

Seja de que espécie for, a diversidade gerada pelas cidades repousa no fato de que nelas muitas pessoas estão bastante próximas e elas manifestam os mais diferentes gostos, habilidades, necessidades, carências e obsessões [...] a maior parte da diversidade urbana é criação de uma quantidade inacreditável de pessoas diversas e de organizações privadas diversas, que têm concepções e propósitos bastantes diversos e planejam e criam fora do âmbito formal da ação pública (JACOBS, 2000, p. 161 e 267).

Ora, considerando que São Luís, segundo dados do Instituto Brasileiro de Geografia e Estatística - IBGE, é o 15o (décimo quinto) Município mais populoso do Brasil, seria interessante que o seu Centro Histórico fosse melhor aproveitado, como forma de difundir a diversidade e firmar a identidade passada. Com uma localização privilegiada e com uma infraestrutura urbana já implantada, seria lógico que o Centro Histórico fosse um lugar de distinção no cenário urbano da de São Luís, inclusive com forte especulação imobiliária! Todavia, a realidade é outra: o capital prefere outras áreas, deixando-se o Centro em um processo de degradação, tornando-se pouco atrativo para fins de habitacionais, comerciais e até culturais. 
Figura 2 - Imóvel posto à venda e objeto de judicialização

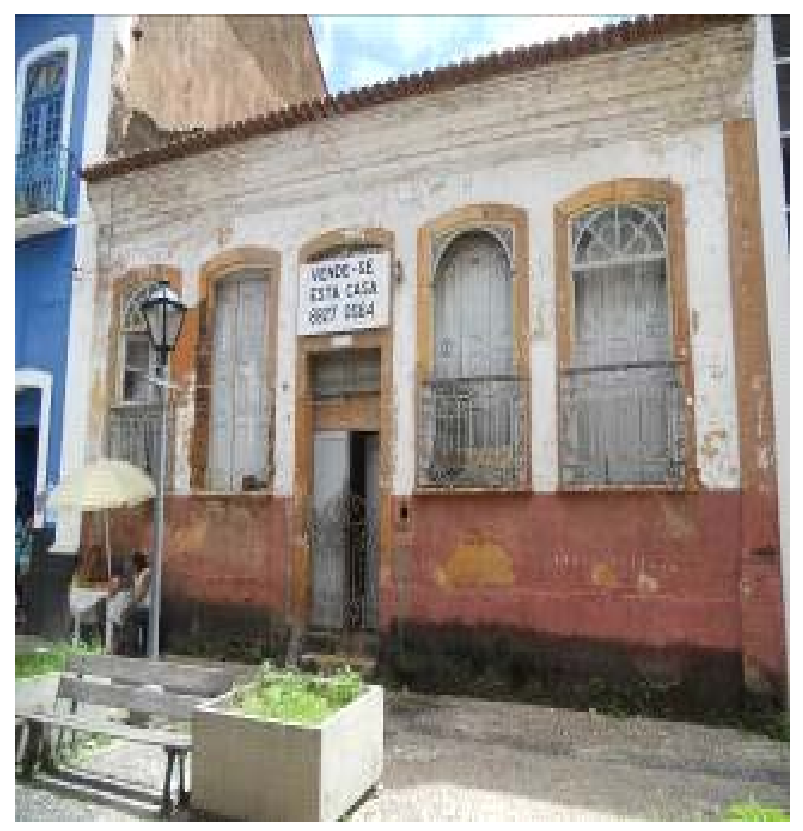

Fonte: arquivo do IPHAN/MA

Não custa lembrar que Jacques Le Goff (1998, p. 150 e 153), por exemplo, vê com bastante ceticismo a existência dos bairros centrais, advertindo que:

Há muito tempo os centros são objeto de ferozes batalhas; eles não querem desaparecer sem combate, eles resistem. Parece-me, entretanto, que a evolução age profundamente contra o centro urbano. Ele não é mais adaptado à vida econômica, à vida das relações que dominam às populações urbanas. Então, o que ele se torna? Centro storico, dizem muito bem os italianos. E se ele ainda brilha, é beleza da morte. Caminha-se em direção ao centro-museu; por outro lado, se os centros têm perdido a batalha econômica, resta-lhe o prestígio cultural, pois, "se o centro perde em energia, ganha em prestígio, é que ele permite ver num relance a cidade: sua beleza o resume. Tal como a heráldica resume o destino de uma família".

Assim, para se entender tal dinâmica, partiu-se para a análise dos processos judiciais, exatamente, onde são discutidas as razões pelas quais determinado proprietário não cuida de seu patrimônio, deixando-o ao abandono. O que dizem os processos judiciais?

Deixe-se claro que este trabalho não desconsidera outros fatores que possam estar levando o Centro Histórico ao abandono. Todavia, por questão de método, procurou-se privilegiar apenas as informações e os discursos contidos nos processos judiciais.

O fator judicialização das relações sociais pode se mostrar como um termômetro dos interesses econômicos de determinados setores. Se há baixa judicialização, pode-se ter um indicativo de que determinada classe de bens tem pouca atratividade, no caso, o casario colonial do Centro Histórico. 
Dessa maneira, para entender a problemática enfrentada pelo Centro Histórico de São Luís, foram elencados 03 (três) fatores, sem qualquer pretensão exauriente, mas a partir da constatação dos dados empíricos, obtidos com a coleta de dados judiciais, a saber: o fator pobreza, a questão da diversidade urbana e, por último, a falta de diálogo com a sociedade civil.

\section{A REALIDADE E O DISCURSO DA POBREZA}

O que acontece com o Centro Histórico de São Luís, que parece não se sintonizar com a diversidade tratada pelos urbanistas, a exemplo de Jane Jacobs (2000)? O que leva um Centro Histórico a ser deixado ao abandono, como se a cidade antiga já não atendesse aos novos anseios de uma cidade seduzida pelo concreto, pelo vidro e outros padrões de consumo emergentes?

Um dos fatores constatados pela pesquisa, por exemplo, verificados a partir da leitura dos autos é o discurso da pobreza, presente nas contestações ou na fase de execução das decisões:



Os processos judiciais analisados demonstram que o fator pobreza (falta de recursos) é um dos discursos mais recorrentes por aqueles que não conseguem dar conta das suas obrigações como proprietários dos imóveis. 


\section{Figura 3 - Imóvel objeto de judicialização}

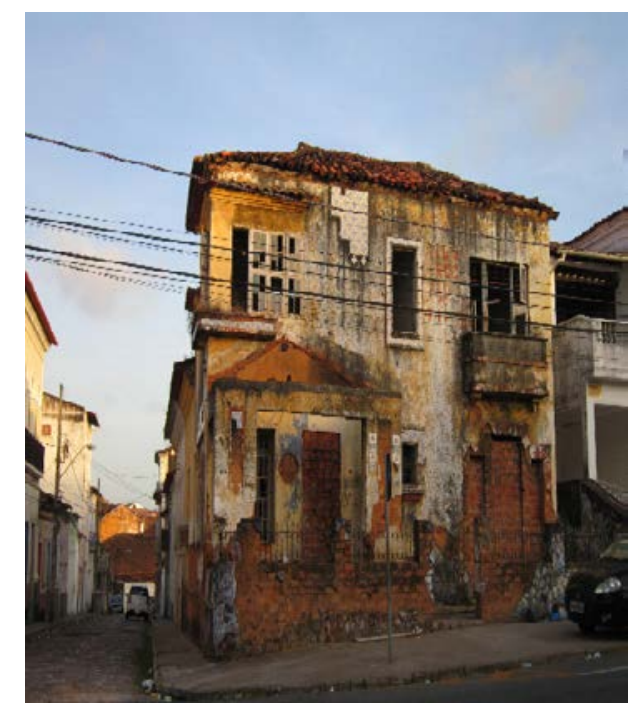

Fonte: arquivo pessoal

Não há um discurso claro de insurgência contra as normas patrimoniais. Os proprietários, em verdade, invocam apenas a sua pobreza para justificar a não adequação. Esse discurso jurídico traduz uma realidade fática que é a pobreza presente na cidade de São Luís. Nesse ponto, as políticas patrimoniais aplicadas ao Centro Histórico jamais poderão desconsiderar a realidade de pobreza do lugar. Mesmo que um ou outro proprietário tenha recursos, em geral, o Centro Histórico virou reduto de pobreza e de empreendimentos ligados ao pequeno capital.

Assim, é essencial que as políticas patrimoniais considerem que as pessoas que ocupam o Centro Histórico, em regra, são pessoas desprovidas de recursos ou que passaram por um processo de decadência econômica, o que condiz com a realidade histórica do declínio econômico do Estado do Maranhão e da cidade de São Luís.

Não custa lembrar que os bens simbólicos, a exemplo dos imóveis objetos de proteção, além de valor político, social e cultural, têm um valor financeiro e que podem seguir uma lógica mercadológica atrativa para empreendedores, de pequeno, médio ou grande portes.

A pesquisa, nesse ponto, observou que um dos graves obstáculos para o cumprimento das decisões judiciais é o argumento de falta de recursos, confirmando que as políticas patrimoniais estão dissociadas de uma lógica que fomente o desenvolvimento econômico das populações interessadas. Em regra, os proprietários dos imóveis são pessoas com poucos recursos financeiros ou que estão em processo de decadência financeira, bem como pequenas empresas: 


\section{Gráfico 2 - Conhecendo a questão: quem esquece o patrimônio (tipo de pessoa)?}

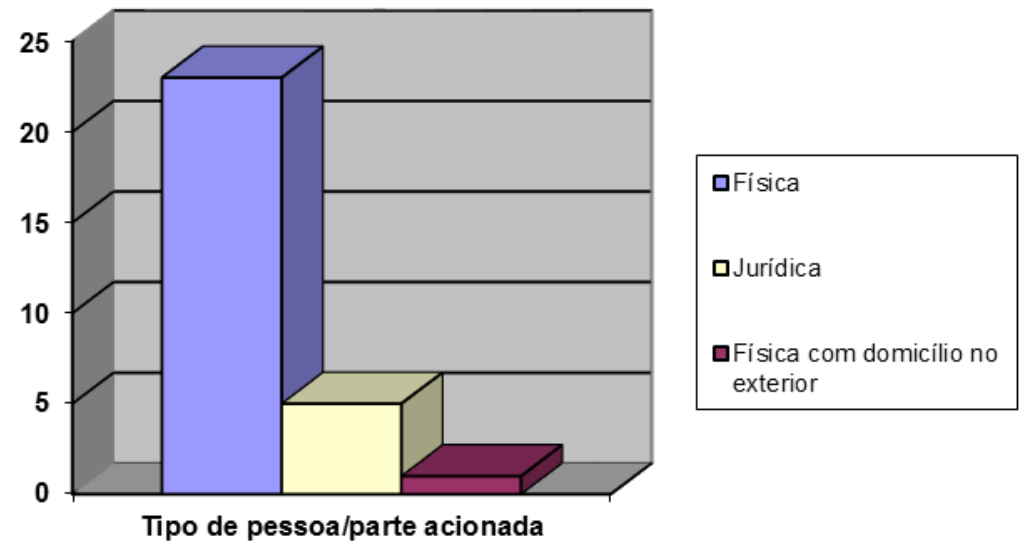

Ora, se há pobreza no Centro Histórico, as causas dessa pobreza devem ser consideradas. Assim, mais uma vez, questiona-se por que os imóveis em São Luís, no Centro Histórico, em vez de valorização passam por um processo de abandono, sendo objeto de constante e ineficiente judicialização?

Como todas as mercadorias, tais bens estão sujeitos a desvalorização e a valorização, no plano cultural (o coletivo, reconhecido através do tombamento, pela harmonia do conjunto), não querendo dizer, necessariamente, que tenha havido valorização no plano econômico do mercado de imóveis, sujeito a falhas que necessitam de interferência estatal. Porém, a interferência estatal deveria ser precedida de diálogo com a sociedade civil, temática a ser tratada adiante. O Estado intervencionista não é o Estado absoluto e insensível ao diálogo com os cidadãos; contrariamente, o Estado interventor é, exatamente, aquele que procura proteger os cidadãos das falhas de mercado, o que pressupõe a prática da alteridade.

Nesse plano, além de não ouvir a sociedade civil, o Estado age em falha de governo porque desconsidera as razões sociais, ideológicas e econômicas, bem como insiste em tratar a questão patrimonial, como um bem cultural, que deve ser gerido apenas por ele mesmo, não fomentando o empreendedorismo e não articulando políticas públicas que tornem o Centro Histórico menos dependente dos orçamentos públicos para a área.

Não se desconsidera que o patrimônio, como bem simbólico, pode ser transformado em objeto de mercadoria cultural do empresariado do setor (LEITE, 2004; FUNARI; PELEGRINI, 2006). No entanto, a tecnocracia patrimonial, por mais que tenha boas intenções, jamais dará conta, sozinha, de gerir a complexidade de um Centro Histórico se não tiver a compreensão das pretensões da sociedade civil e dos agentes econômicos que desenvolvem alguma atividade nele. 
À política patrimonial aplicada no Centro Histórico de São Luís parece faltar certo empreendedorismo a fomentar sua emancipação. Não se pode esquecer que se vive em uma sociedade capitalista, a qual é uma sociedade de proprietários de mercadorias (PASUKANIS, 1989) e, nesse sentido, parece que o conjunto imobiliário do Centro Histórico não se mostra como mercadoria de valia, já que se vê ao abandono e que espera, como último grito de socorro, um ato de misericórdia vindo das Instituições do Sistema de Justiça.

Nesse viés, se as leis costumam ser reflexo dos fatores reais de poder que regem a sociedade (LASSALE, 2001), a política patrimonial deve atentar para esses fatores, inclusive em relação aos tipos de capital que poderiam se articular consigo, buscando novas formas para se deixar o Centro Histórico atrativo. Atrair o capital não quer dizer, por outro lado, que o Estado vá deixar a questão sob a inteira regência do mercado; contrariamente, o Estado, ouvindo e dialogando com a sociedade civil, deve agir, corrigindo as falhas do mercado, intervindo, mas tornando-o atrativo sob o ponto de vista econômico, cultural, político e social, o que representaria a efetiva simbiose de um processo de desenvolvimento.

O que não se pode conceber é a exclusão da sociedade civil ou que apenas o Estado monopolize os discursos e as ações, seja através de seus órgãos e entidades seja através das Instituições do Sistema de Justiça.

Constatado o fator pobreza dos proprietários, como um fator essencial para se entender a problemática, inclusive considerando que tanto os projetos quanto a execução de obras de recuperação do casario constituem despesas elevadas, deve-se partir para um outro ponto, indagando-se por que uma área urbana de "pobreza" não atrai investimentos do setor imobiliário?

\section{A FALTA DE ESTÍMULOS À DIVERSIDADE URBANA}

A resposta à pergunta acima parece estar na falta de fomento à diversidade econômica do Centro Histórico ou, talvez, na não atração de novos polos econômicos para a área, impedindo que o Centro contribua para a necessária diversidade urbana de São Luís. 
Figura 4 - Imóvel objeto de judicialização, em processo de recuperação, e que abrigará uma escola de música municipal

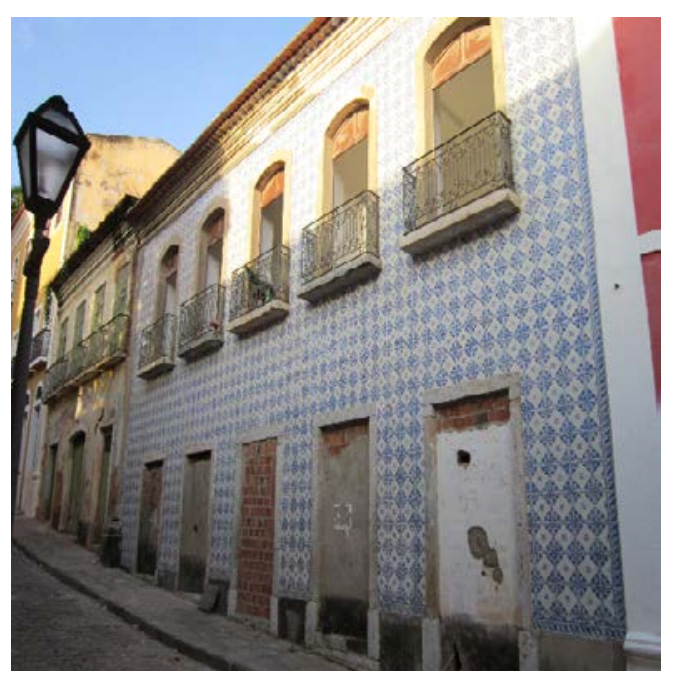

Fonte: arquivo pessoal

Sobre essa temática, a diversidade urbana que um Centro Histórico proporciona, Jane Jacobs (2000) entende que as cidades precisam tanto de prédios antigos, que talvez não seja possível a obtenção de ruas e distritos vivos sem eles: "ideias antigas às vezes podem lançar mão de prédios novos. Ideias novas devem lançar mão de prédios antigos", pois isso proporcionará a diversidade necessária para o florescimento e mistura de empresas de altos, médios e baixos rendimentos.

Se uma área da cidade tiver apenas prédios novos, as empresas que venham a existir aí estarão automaticamente limitadas àquelas que podem arcar com os custos dos novos edifícios. O alto custo da ocupação dos prédios novos pode ser compensado na forma de aluguéis ou na forma de pagamento de juros e amortização pelo proprietário sobre o custo investido da construção. Seja como for, os custos precisam ser pagos. Por essa razão, as empresas que podem arcar com o custo das construções novas devem ser capazes de arcar com uma despesa fixa relativamente alta - alta em comparação com o que necessariamente se exige em prédios antigos [...] Redes de lojas, redes de restaurantes e bancos instalam-se em novas construções. Mas bares de bairro, restaurantes típicos e casas de penhores instalam-se em prédios antigos. Supermercados e lojas de calçados geralmente se instalam em prédios novos; boas livrarias e antiquários raramente o fazem. Teatros líricos e museus de artes subvencionados instalam-se em prédios novos. Mas os fomentadores informais das artes - estúdios, galerias, lojas de instrumentos musicais e de material artístico, salas dos fundos onde os negócios de fundo de quintal de baixo rendimento, permitem travar uma conversa prolongada , esses se instalam em prédios antigos (JACOBS, 2000, p. 207-208).

Em São Luís, mesmo com as tentativas de se dar novos usos ao casario do Centro Histórico, percebe-se certo insucesso da política patrimonial, o que pode ser comprovado com os casos que 
são judicializados pelo próprio Estado junto à Justiça Federal, sendo pouco conhecidas ações ajuizadas por cidadãos, através de ações populares, e até dos empresários em favor de seus bens.

O raciocínio acima, por exemplo, é comprovado, pela observação da judicialização, através dos atores que tiveram conhecimento da questão. De acordo com o gráfico abaixo, a sociedade civil tem diminuta participação nas demandas patrimoniais, havendo um protagonismo dos órgãos burocráticos judicantes do Estado (Advocacia-Geral da União - AGU e Ministério Público Federal MPF):

\section{Gráfico 3 - Conhecendo a questão: para quem o patrimônio foi lamentar suas dores?}

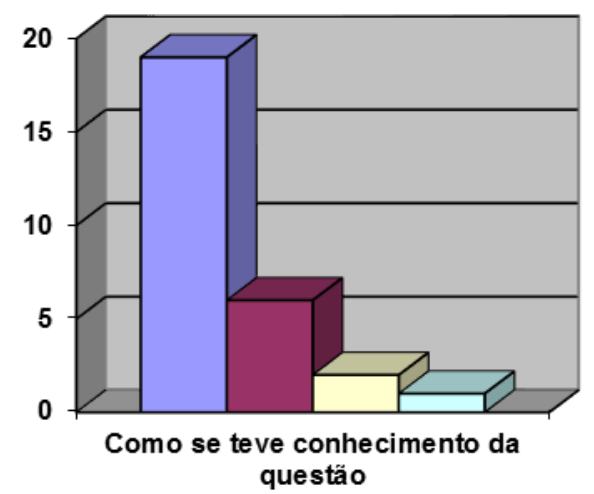

QVistoria do IPHAN

-Representação de Agente Político

םRepresentação do Corpo

de Bombeiros/Defesa Civil

口Representação de cidadão

\section{Gráfico 4 - Conhecendo a questão: quem defende o patrimônio?}
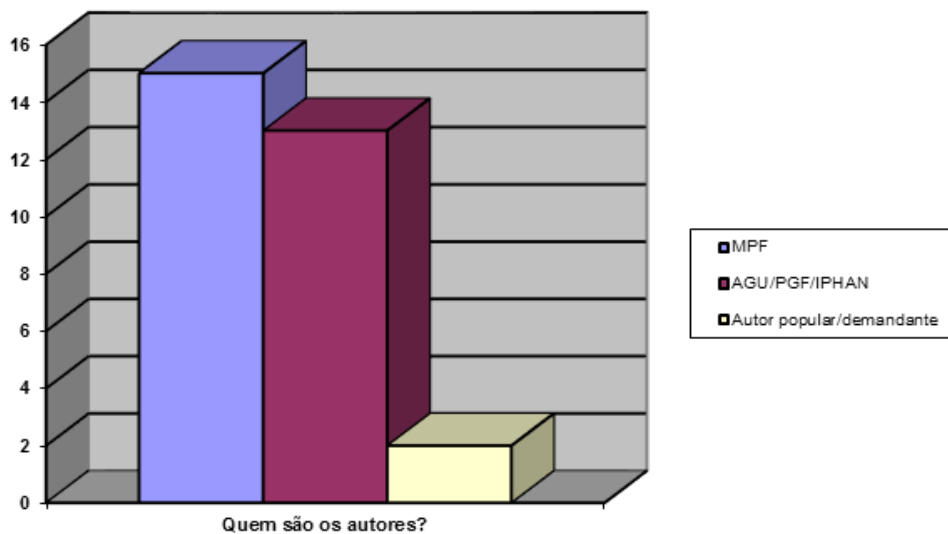

Os gráficos demonstram a pouca participação da sociedade civil nas demandas patrimoniais, o que bem reflete o desencantamento daquela em relação ao próprio papel do Estado que julga tais ações. 
Em relação ao ajuizamento de ações populares, por exemplo, em prol do patrimônio, tal instrumento é pouco utilizado para proteger o Centro Histórico de São Luís. Na pesquisa, encontrou-se um caso, mas que não teve como objetivo proteger o patrimônio cultural em si, mas manter um ato administrativo que destinava determinado imóvel para o Curso de História da Universidade Estadual do Maranhão - UEMA, em que um grupo de professores do Departamento de História ajuizou uma ação popular, sob os autos de no 0004096-31.2012.4.01.3700, objetivando ver anulado um ato administrativo que transferia do Estado do Maranhão para o IPHAN um imóvel localizado na Rua da Estrela, ao lado do Teatro João do Vale.

\section{Figura 5 - Imóvel objeto de judicialização, em processo de recuperação, e que abrigará a Casa do Tambor de Crioula}

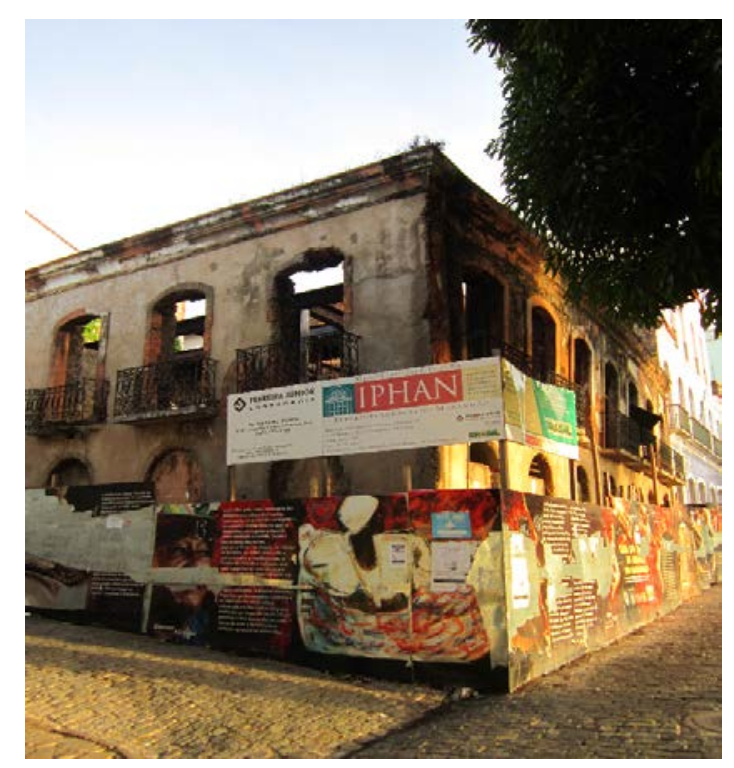

Fonte: arquivo pessoal

Nesse imóvel, o IPHAN instalará a Casa de Tambor de Crioula, enquanto os professores pretendiam que o imóvel fosse destinado como anexo do prédio do Curso de História, que fica ao lado. Após o Estado do Maranhão ter destinado um outro imóvel para o Curso de História, também, ao lado do prédio atual, os autores desistiram da ação, que foi extinta sem resolução do mérito, por falta de interesse processual.

Esse protagonismo dos órgãos burocráticos judicantes do Estado, nas ações analisadas na pesquisa, tem como aliado uma defesa judicial relativamente passiva por parte dos proprietários de imóveis acionados: alguns sequer contestam os pedidos; outros não recorrem; uns jamais atendem aos apelos judiciais. Essas condutas demonstram que, efetivamente, os agentes 
econômicos não estão muito interessados no Centro Histórico, presumindo-se que estejam interessados por outras áreas da cidade, o que compromete a própria diversidade urbana de São Luís e, consequentemente, o declínio do Centro.

Gráfico 5 - Posturas processuais/bons réus: houve insurgência/recurso para o TRF em relação à decisão inicial?

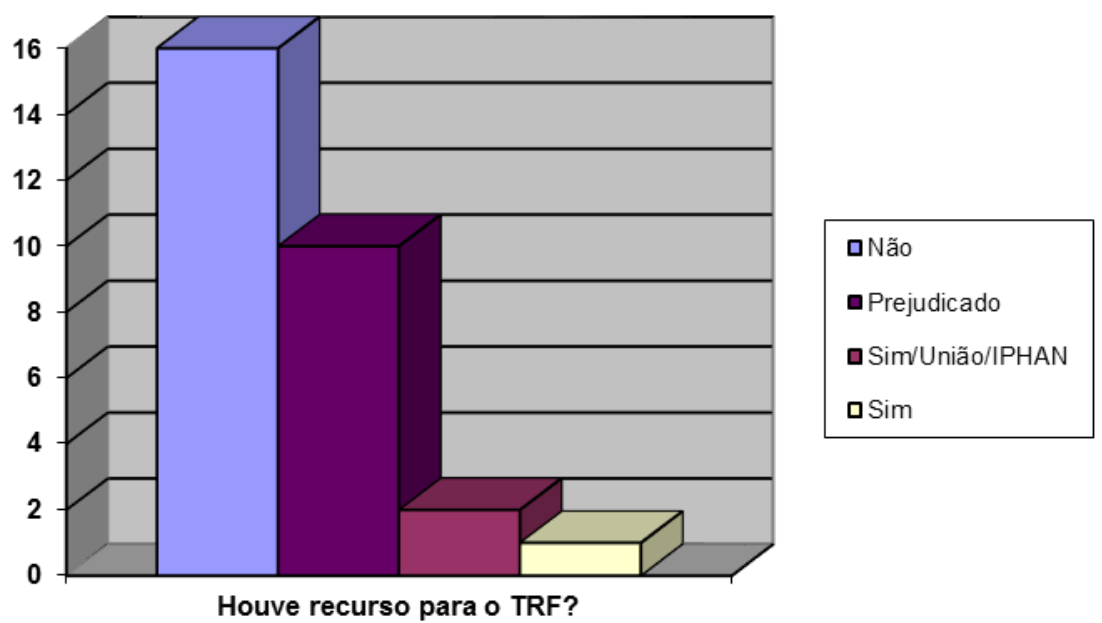

O gráfico acima demonstra que os proprietários podem ser considerados "bons réus", em linguagem metafórica, pois sequer costumam apresentar recurso de agravo de instrumento contra as decisões iniciais que determinam a reforma de um imóvel. Em termos de processo, um réu (acionado) que não recorre apresenta uma vantagem para aquele que ajuíza uma ação (autor/acionante). Isso poderia ser um fator positivo em favor do patrimônio cultural da cidade, partindo-se da premissa segundo a qual o processo demoraria menos tempo para terminar e, consequentemente, ter-se efetividade. Porém, a efetividade é duvidosa. 


\section{Gráfico 6 - Posturas processuais: houve contestação?}

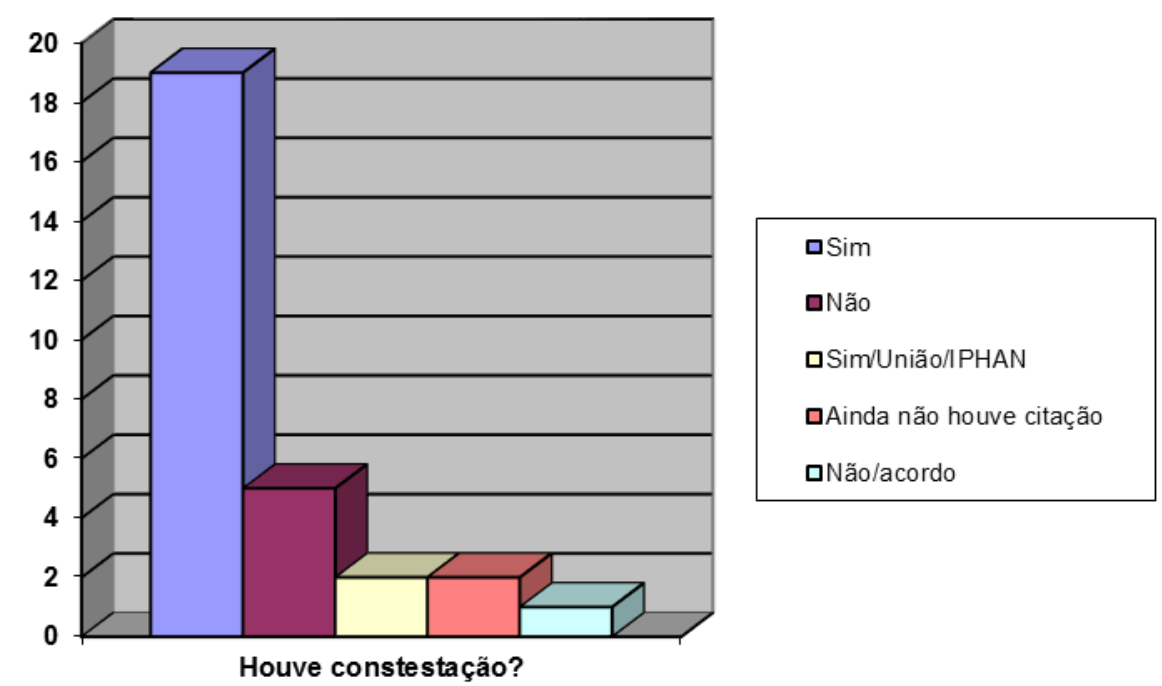

Diferentemente da fase de recurso, os réus (acionados) costumam apresentar a contestação, momento no qual informam as razões pelas quais deixaram de cuidar de seu imóvel. É, principalmente, nesse momento que os proprietários costumam alegar a falta de recursos financeiros como razão a falta de manutenção dos imóveis.

\section{Gráfico 7 - Posturas processuais/bons réus: existência de atos procrastinatórios?}

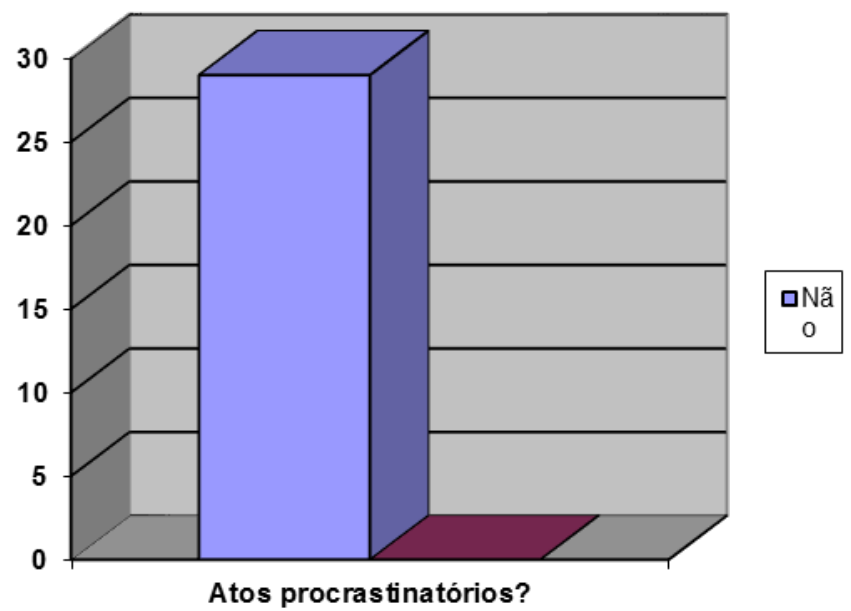

A judicialização brasileira tem a pecha de ser permeada por atos que são chamados de procrastinatórios (recursos sem a devida fundamentação, pedidos impertinentes etc.), ou seja, atos processuais, tomados pelas partes, que visam impedir o cumprimento de uma decisão ou 
retardar o fim do processo. Porém, nos processos analisados, verificou-se que as partes dificilmente tomavam tais posturas processuais, o que leva a crer que o discurso de pobreza como impeditivo para cuidar de seus imóveis é uma alegação sincera.

\section{Gráfico 8 - Posturas processuais/bons réus: houve apelação?}

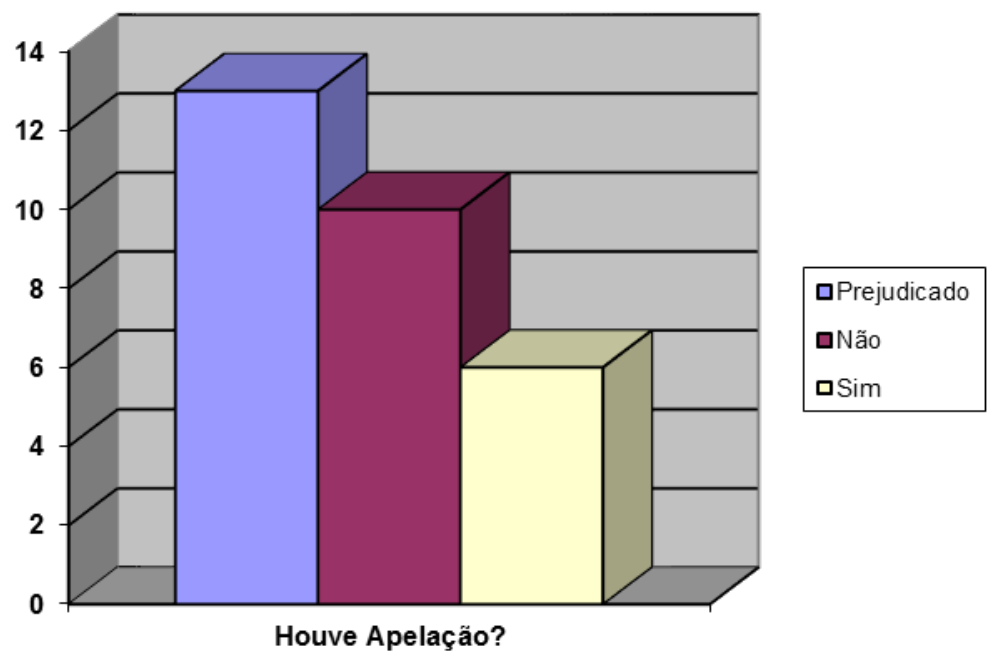

O recurso de apelação é relativamente simples, sendo apresentado após o juízo proferir a sentença. Apesar dessa simplicidade, boa parte dos réus (acionados) não costuma interpor tal recurso. Assim, como o recurso de agravo de instrumento, interposto contra uma decisão inicial, a ausência de recurso de apelação seria uma vantagem para aquele que ajuíza a ação (autor/acionado) e, consequentemente, para o patrimônio cultural da cidade, pois indicaria que a decisão judicial seria logo cumprida: essa normatividade processual é quebrada pela realidade fática. 


\section{Gráfico 9 - Posturas processuais/bons réus: houve recurso especial?}

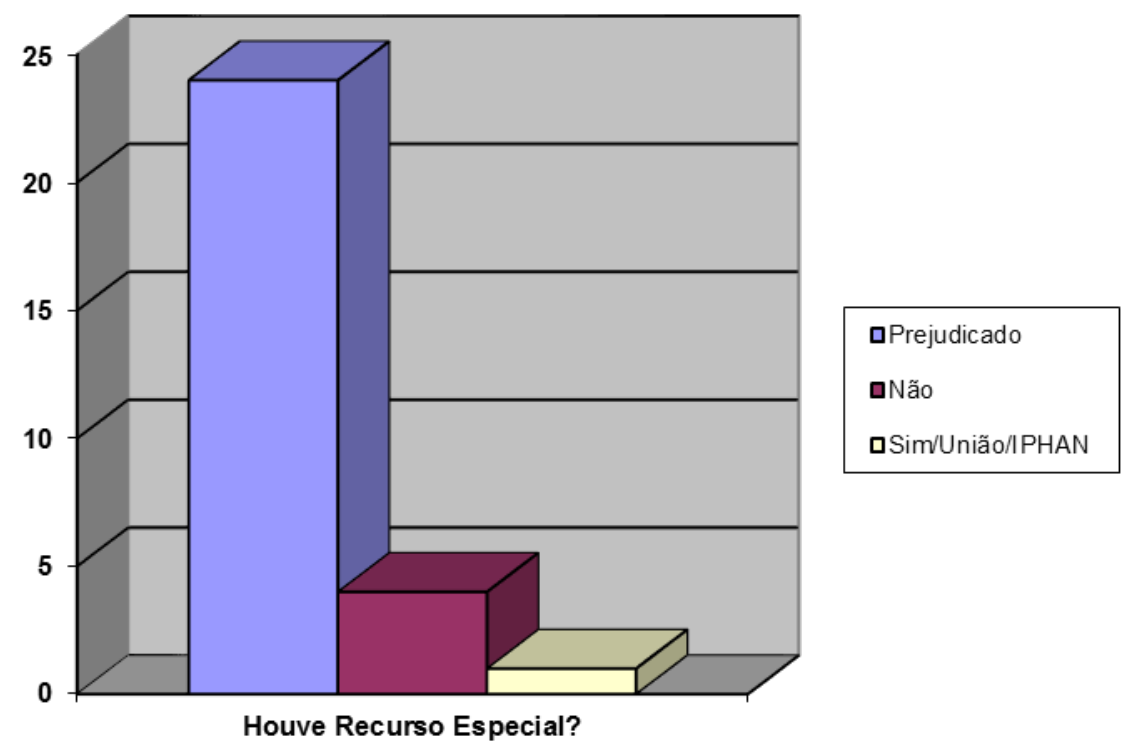

O recurso especial também é pouquíssimo utilizado pelos proprietários, aplicando-se o mesmo raciocínio a respeito do recurso de agravo de instrumento e do recurso de apelação: a ausência de recurso especial seria uma vantagem para aquele que ajuíza a ação (autor/acionado), e, consequentemente, para o patrimônio cultural da cidade, pois indicaria que a decisão judicial seria logo cumprida: essa normatividade processual é quebrada, também, pela realidade fática.

Gráfico 10 - Posturas processuais: houve início da execução da sentença?

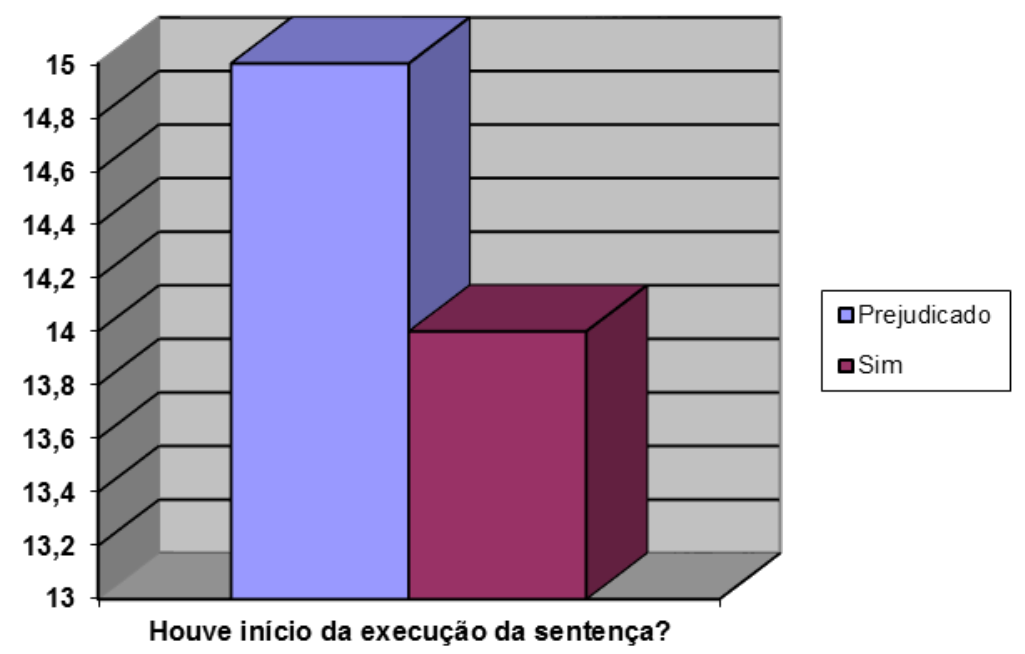


Após, finalizado o processo de conhecimento, parte-se para a fase de execução da sentença em favor do patrimônio. Muitas vezes, essa fase demora para iniciar, o que retarda a efetividade das decisões. Os casos nos quais constam como prejudicados correspondem aos processos que ainda não transitaram em julgado, os quais não podem ser objeto de execução definitiva.

\section{Gráfico 11 - Posturas processuais: houve pedido judicial objetivando constranger o acionado?}

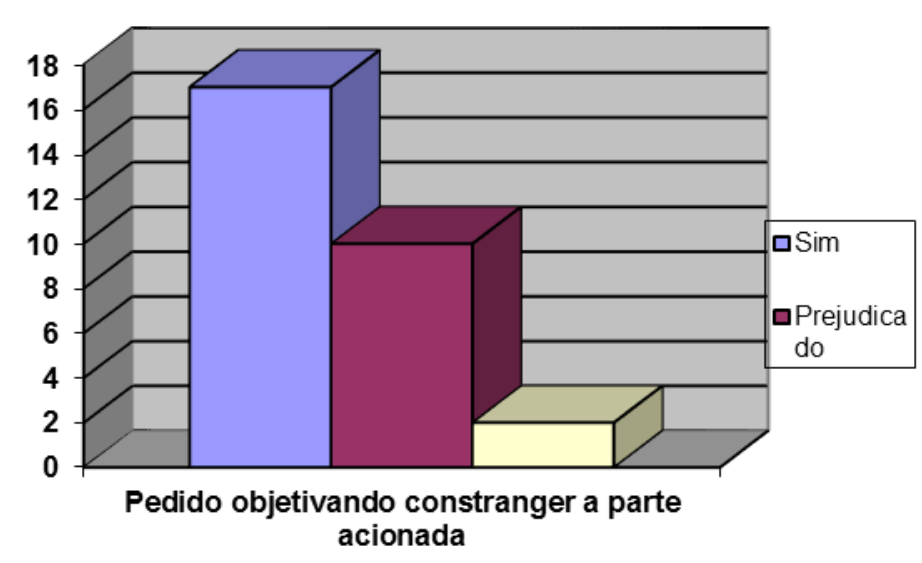

Sendo os proprietários, aparentemente, "bons réus", poderia se indagar por quais razões as decisões judiciais não são cumpridas. Haveria omissão dos órgãos judicantes do Estado (Advocacia-Geral da União - AGU ou Ministério Público Federal - MPF)?

Dos processos analisados, não se percebeu qualquer desleixo processual por parte desses órgãos. As medidas processuais que deveriam ser tomadas foram requeridas. Então, qual seria o problema? A problemática parece ser reconhecer que a normatividade dos órgãos burocráticos e judiciais não é capaz de modificar a facticidade das relações sociais existentes no Centro Histórico, inclusive o fator pobreza (falta de recursos) que impede uma boa parcela dos proprietários de cumprir com suas obrigações patrimoniais.

Não bastasse isso, mesmo com prédios revitalizados em decorrência do cumprimento de uma decisão judicial, não há projetos para depois da revitalização. Não há uma política patrimonial que diga o que a Cidade de São Luís pretende com o seu singular Centro Histórico. O que ele representa, efetivamente, para a cidade? Seriam as representações do patrimônio apenas devaneios coletivos, e o direito à cidade seria apenas uma cilada discursiva? O que a sociedade civil pensa sobre o seu patrimônio? 


\section{SOBRE A INEXISTÊNCIA DE UM NECESSÁRIO DIÁLOGO COM A SOCIEDADE CIVIL}

Respondendo ao questionamento anterior, para que a política patrimonial se mostre eficiente, as Instituições do Sistema de Justiça não podem ter a tola pretensão de cobrir os déficits de cidadania e de atuação da sociedade civil, ou pensar que serão mais eficientes do que os órgãos burocráticos que gerenciam as políticas do patrimônio.

Caso os órgãos das Instituições do Sistema de Justiça (Advocacias Pública e Privada, Defensoria Pública, Judiciário e Ministério Público) desconsiderem a necessidade de ouvir e de dar oportunidade de participação à sociedade civil e aos agentes econômicos, bem como enxerguem a questão patrimonial apenas como "uma questão da Justiça", tais órgãos judicantes/burocráticos incidirão nos mesmos equívocos dos órgãos e entidades que fazem a gestão executiva do patrimônio, por desconsiderarem o denominado espaço público que envolve a temática, que não se confunde com espaço urbano. Segundo Rogério Prença Leite (2004, p. 287),

Os limites e diferenças entre um espaço urbano e um espaço público podem contribuir para que seja compreendida a dupla inserção conceitual entre espaço e sociabilidade pública, entendendo aqui essa sociabilidade de modo amplo, como práticas interativas - conflitivas ou não - que ocorrem na vida cotidiana pública. Como já pude sugerir em capítulo anterior, uma noção de espaço público que não inclua as práticas interativas entre os agentes envolvidos na construção social do seu espaço seria apenas uma noção que se estaria referindo a um espaço urbano. Inversamente, uma noção que prescinda de uma referência espacial para essas ações interativas pode ser entendida como uma esfera pública. Quando, portanto, há uma convergência entre as categorias espaço e ação, podemos entender que se tem um espaço público, formado da intersecção entre espaço urbano e a esfera pública, construtos dos quais retira, respectivamente, as categorias que Ihe são constitutivas: espaço e ação. Essa intersecção não resulta de um mero somatório de categorias distintas, mas deve ser compreendida como resultante da convergência prática entre o exercício de uma sociabilidade pública e os espaços que por ela são construídos, nunca dados a priori.

Dando continuidade à discussão em torno do espaço público, Jürgen Habermas (2003) reconhece que há uma arena de direitos e que o direito é essencial à vida em sociedade, defendendo que o ideal democrático não pode ser realizado sem a participação de todos ou apenas no reconhecimento normativo, pois a ordem jurídica não pode se limitar apenas a garantir o reconhecimento abstrato de direitos, devendo haver um reconhecimento recíproco dos direitos de cada um por todos os outros; o reconhecimento de direitos, por sua vez, deve se apoiar em leis legítimas que garantam liberdades iguais, de modo que 'a liberdade do arbítrio de cada um possa manter-se junto com a liberdade de todos'. Evidentemente, normas legítimas pressupõe participação daqueles que experimentarão tais normas. 
Dessa forma, para Jürgen Habermas (2003), o cidadão deve sair do papel de consumidor passivo do direito, para sujeito ativo da construção do direito, no que faz um resgate semântico do ideal aristotélico de homem público, que é responsável pela construção normativa das regras as quais os cidadãos estarão submetidos.

Nas palavras de Jürgen Habermas (2003, p. 53),

No sistema jurídico, o processo da legislação constitui, pois, o lugar propriamente dito da integração social. Por isso, temos que supor que os participantes do processo de legislação saem do papel de sujeitos privados do direito e assumem, através de seu papel de cidadãos, a perspectiva de membros de uma comunidade jurídica livremente associada, na qual um acordo sobre os princípios normativos da regulamentação da convivência já está assegurado através da tradição ou pode ser conseguido através de um entendimento segundo regras reconhecidas normativamente. Essa união característica entre coerção fática e validade da legitimidade, que tentamos esclarecer através do direito subjetivo à assunção estratégica de interesses próprios, exige um processo de legislação no qual os cidadãos devem poder participar na condição de sujeitos do direito que agem orientado não apenas pelo sucesso. Na medida em que os direitos de comunicação e de participação política são constitutivos para um processo de legislação eficiente do ponto de vista da legitimação, esses direitos subjetivos não podem ser tidos como os de sujeitos jurídicos privados e isolados: eles têm que ser apreendidos no enfoque de participantes orientados pelo entendimento, que se encontram numa prática intersubjetiva de entendimento. É por isso que o conceito do direito moderno - que intensifica e, ao mesmo tempo, operacionaliza a tensão entre facticidade e validade na área do comportamento - absorve o pensamento democrático, desenvolvido por Kant e Rousseau, segundo o qual a pretensão de legitimidade de uma ordem jurídica construída com direitos subjetivos só pode ser resgatada através da força socialmente integradora da 'vontade unida e coincidente de todos' os cidadãos livres e iguais.

Para tanto, a irracionalidade da dominação só poderá ser suplantada por uma formação política da vontade vinculada ao princípio da discussão universal e livre de coerção, em que o poder político advenha de um pensamento comprometido com o diálogo, pois a força libertadora da reflexão não pode ser substituída pela propagação do saber tecnicamente utilizável (HABERMAS, 2013), ou seja, por mais qualificados que sejam os órgãos burocráticos do patrimônio, estes não podem desconsiderar a sociedade civil.

Nesse contexto, a força da sociedade deve ser reafirmada, através de uma prática de autodeterminação que exigiria dos cidadãos o exercício comum de suas liberdades comunicativas, de onde o direito retiraria sua força integradora das fontes de solidariedade social, mesmo se reconhecendo a existência de forças de mercado, pois as sociedades modernas são integradas não 
somente através de valores, normas e processos de entendimento, mas, de forma igual, através de mercados e do poder administrativo (HABERMAS, 2003).

Fazendo-se a aplicação da teoria de Habermas, uma coisa parece certa, há um pecado mortal nas políticas patrimoniais do Centro Histórico de São Luís: não há diálogo com a sociedade civil, que é mero receptáculo daquilo que inventado pela tecnocracia como sendo o patrimônio a ser preservado. Nesse sentido, Alexandre Fernandes Corrêa (2003) questiona o processo de revitalização do Centro Histórico, no que diz respeito à ausência de participação da sociedade civil. Afirma o autor:

Revitalização é um processo desencadeado no sentido de fazer retornar, preservar, conservar e promover as características de algo que perdeu o vigor histórico. Quem vai decidir o que deve, ou não, ser revitalizado? Quase nunca são ouvidos aqueles diretamente ligados ao problema, isto é, as comunidades que moram nos bairros históricos são sempre negligenciadas. Como exemplo disso, cito o projeto de habitação no Centro Histórico. Nessa ocasião foram contatadas pessoas do interior que desejassem morar em São Luís, lhes foram entregues moradias em apartamentos reformados, limpos e higienizados.

No dizer dos administradores, a população contatada não tinha 'padrões de conduta' condizentes com as diretrizes esperadas pelos promotores. A incompreensão mútua gerou novos problemas; uma população semialfabetizada não conseguiu reproduzir padrões formulados por arquitetos e engenheiros - ao ponto de surgirem problemas básicos de higiene pessoal, como no uso de banheiros. O projeto sucumbiu, mas faz-se necessário compreender as razões deste fracasso (CORRÊA, 2003, p. 131132).

Da falta de participação da sociedade civil, cria-se um vácuo entre aquilo que é pensado pela tecnocracia patrimonial e a vivência daqueles que usufruirão do Centro Histórico, que, aos poucos, vem se tornando apenas como uma espécie de estorvo patrimonial, habitado pelas classes menos favorecidas economicamente, enquanto, inclusive, a Administração Pública, em diversos níveis, trata de abandoná-lo em fuga para outras áreas da cidade. Consoante Alexandre Fernandes Corrêa (2003, p. 135),

A participação da comunidade é imprescindível e essencial. Contudo é quase sempre esquecida. Em São Luís, por exemplo, para o bem, e para o mal também, a população carente do centro histórico conservou prédios, ruas, sobrados, montando e gerenciando cortiços, pensões, bordéis, dormitórios etc. $\mathrm{O}$ abandono dos prédios pelos herdeiros da antiga burguesia comercial maranhense resultou num processo de ocupação popular do sítio histórico. O surpreendente nesse caso é que o sítio histórico não 'morreu', continuou vivo nessas ações heterodoxas de preservação efetuadas pela população que se apossou destes prédios. Cabe avaliar essas ações 'preservacionistas' da população e ouvir o que elas pensam sobre o processo de patrimonialização que atualmente está se dando na área. 
O caso do Centro Histórico de São Luís é típico, cada bairro que compõe o conjunto do sítio histórico Federal e Estadual (e agora Mundial) possui uma especificidade, uma característica própria. O que parece ser um ponto de vista razoável é acreditar na possibilidade de se conseguir conservar a área dos bairros históricos como locais residenciais e não só como espaço comercial e turístico.

Do insucesso e da desarticulação da política patrimonial, esta última acaba indo buscar respostas no Judiciário. E tais respostas seriam mais adequadas ou representariam um nível de melhor correção? Ao que tudo indica, a resposta é negativa, pois não se pode acreditar que as Instituições do Sistema de Justiça, através do Judiciário e da judicialização, farão melhor análise dos problemas ou que darão a melhor reposta às políticas públicas que tratam do Centro Histórico de São Luís. O nível de efetividade da judicialização é bastante duvidoso e, quando há efetividade, há que se questionar se vale a pena esperar por respostas tão morosas. Os gráficos abaixo, por exemplo, procuraram analisar a efetividade das decisões proferidas pela Justiça Federal:

\section{Gráfico 12 - O patrimônio que padece/o martelo que nem tudo pode: houve cumprimento da decisão inicial?}

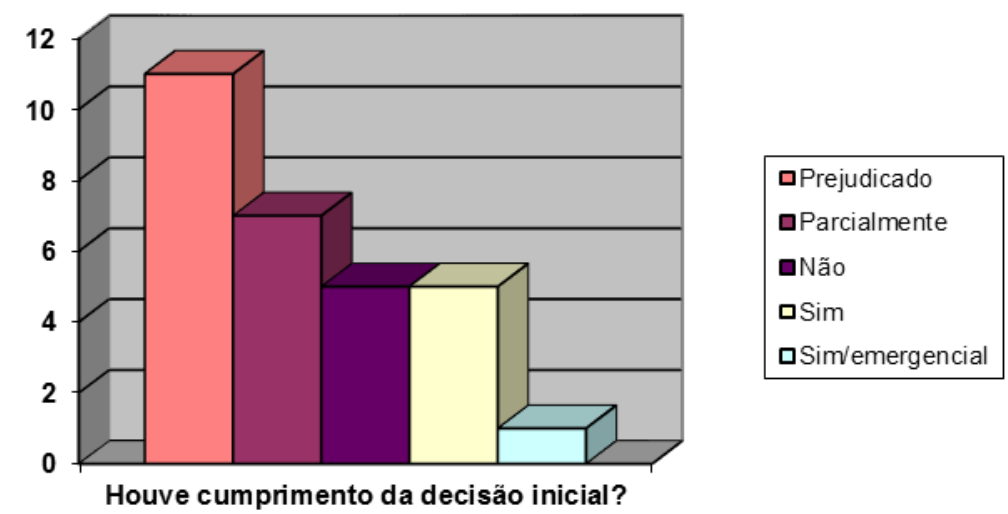

Decisões envolvendo a tutela do patrimônio cultural em São Luís não costumam ser plenamente cumpridas e a bem da verdade isso não é exclusividade dessa questão, sendo problema crônico do sistema judiciário brasileiro. Como já se verificou antes, o fator pobreza (falta de recursos) é um impeditivo real ao cumprimento de qualquer decisão, pois os projetos de restauração e a execução de obras exigem somas razoáveis de recursos. Se os proprietários não possuem recursos, pouco adiantará uma decisão judicial determinando a restauração do imóvel, pois a execução daquela estará comprometida por uma facticidade impossível de ser alterada pela normatividade processual. 
Gráfico 13 - O patrimônio que padece: houve cumprimento efetivo das decisões em favor do patrimônio?

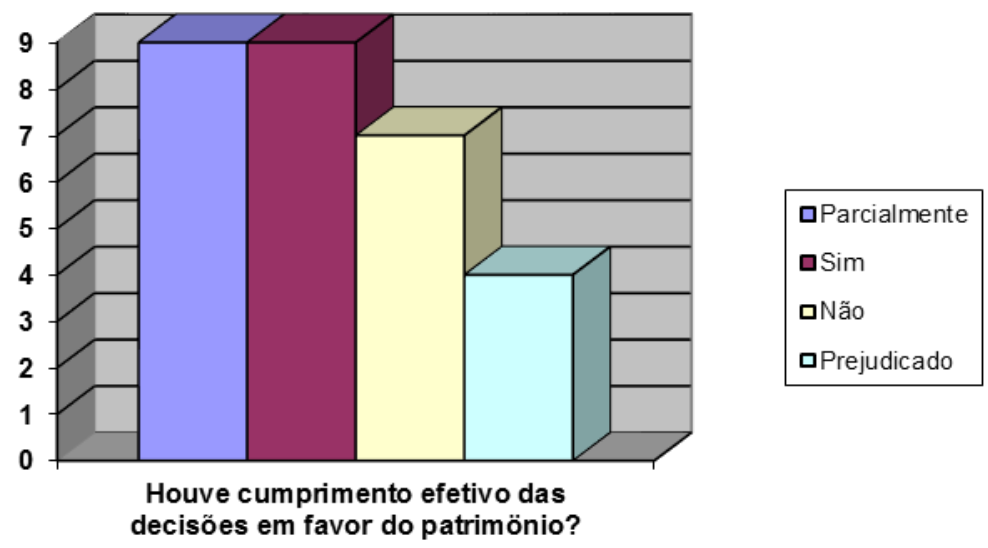

O gráfico acima demonstra que o número de decisões que não foram cumpridas ou que foram cumpridas parcialmente supera o número de decisões em que houve cumprimento efetivo.

Gráfico 14 - O patrimônio que padece: houve problemas na execução da sentença?

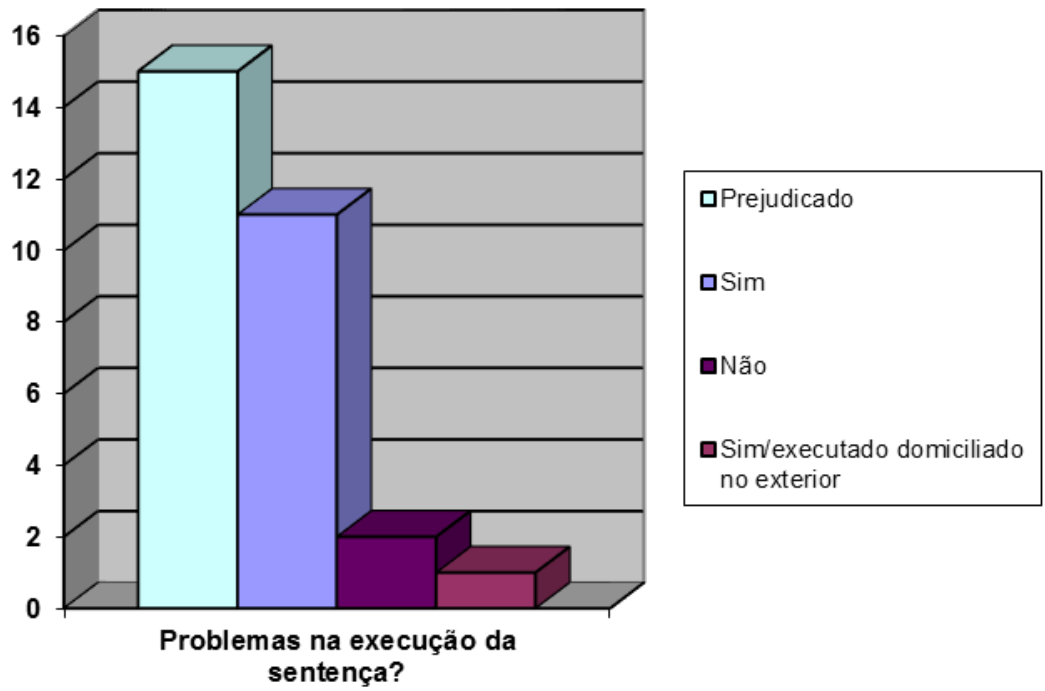

Problemas na execução das decisões em favor do patrimônio também são recorrentes, causando demora na efetividade da tutela do patrimônio cultural. 


\section{Gráfico 15 - O patrimônio que padece/Justiça serve? Houve melhorias no imóvel decorrentes da judicialização?}
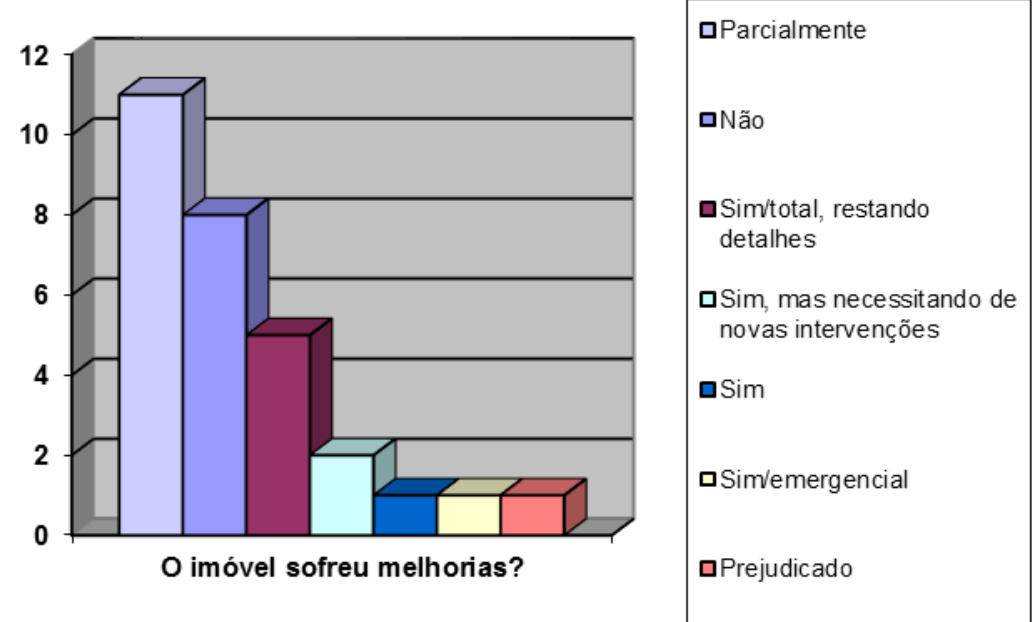

Outro fator que deve ser levado em conta é indagar se, apesar de uma decisão favorável ao patrimônio cultural, houve melhorias no imóvel, ou seja, se o imóvel recebeu alguma obra que o beneficiasse, resgatando-Ihe a sua patrimonialidade. O gráfico acima demonstra que isso nem sempre ocorre.

\section{Gráfico 16 - O patrimônio que padece: o imóvel desabou?}

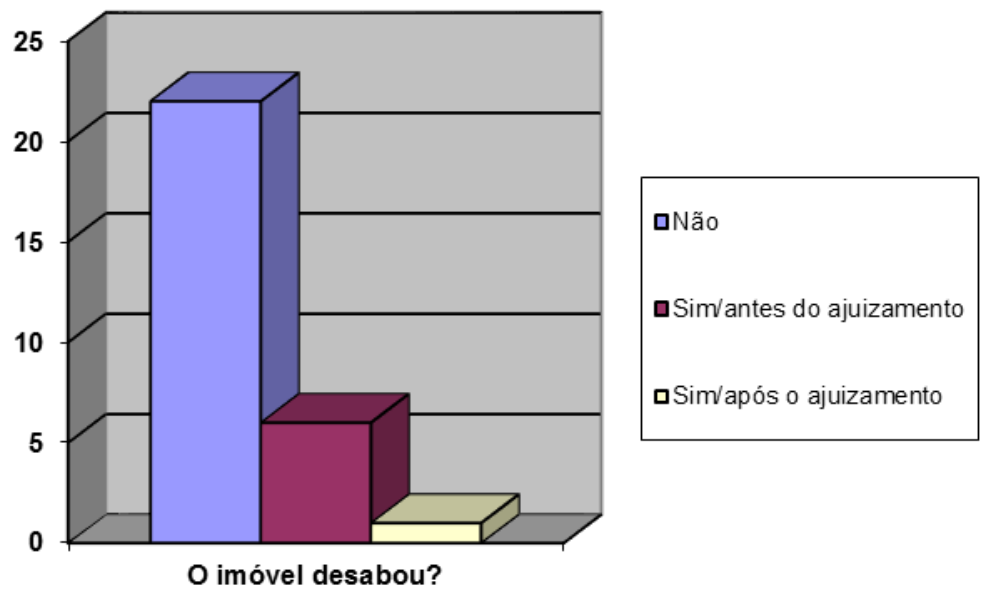

Não se pode esquecer que há casos nos quais, mesmo com uma decisão judicial em favor da restauração de um imóvel, houve desabamento do mesmo, demonstrando-se que nem sempre uma medida judicial mostrará eficácia. 
Com esses dados, não quer se desmerecer a função judiciária; porém, fazer uma reflexão a respeito da banalização de discussões que deveriam estar sendo travadas em outras esferas públicas. Fugir ao debate acerca do acerto das políticas públicas patrimoniais, deixando-lhe ao encargo do Judiciário, é criar uma falsa expectativa de efetividade. O Judiciário não possui poderes mágicos, muito menos será capaz de suprir os debates públicos que deveriam estar competindo à sociedade civil, totalmente bloqueada, incapaz de discutir e deliberar.

Nesse sentido, vale trazer à tona esse "endeusamento" da atividade judiciária. Ao analisar o fetichismo judicial dos Estados Unidos, Jeremy Waldron (2003) recorda que se construiu um retrato idealizado da atividade de julgar que foi emoldurado junto com o retrato de má fama do legislare acrescentar-se-ia, agora, a atividade de administrar. Diz Jeremy Waldron (2003, p. 50) que

As pessoas convenceram-se de que há algo indecoroso em um sistema no qual uma legislatura eleita, dominada por partidos políticos e tomando suas decisões com base no governo da maioria, tem a palavra final em questões de direito e princípios. Parece que tal fórum é considerado indigno das questões mais graves e sérias dos direitos humanos que uma sociedade moderna enfrenta. O pensamento parece ser que os tribunais, com suas perucas e cerimônias, seus volumes encadernados em couro e seu relativo isolamento ante a política partidária, sejam um local mais adequado para solucionar questões desse caráter.

À má fama do legislador, tratada acima por Jeremy Waldron (2003), no Brasil, poder-se-ia acrescentar a má fama do administrador no âmbito da Administração Pública, tida como incapaz de atender às diversas demandas que the são conferidas.

Se o Estado não dialoga com a sociedade civil a respeito das políticas públicas que são criadas ou implementas, não se acredita que o Judiciário fará esse debate, muito menos que dará melhores respostas.

Sendo o Estado uma realidade ideológica (PASUKANIS, 1989), essa ideologia é refletida no direito e nos agentes que o aplicam, seja na Administração Pública ou nas Instituições do Sistema de Justiça. Logo, as respostas do Judiciário, evidentemente, serão permeadas pela ideologia daqueles que atuam nessa função estatal, o que nem sempre corresponderá aos anseios daqueles que vivenciarão tais respostas.

Portanto, o Estado, ao traçar políticas públicas patrimoniais, deve criar mecanismos de diálogo com a sociedade civil, sob pena de se criar uma normatividade totalmente dissociada da facticidade. 
Insistir em implementar uma realidade normativa, dissociada de um diálogo com a sociedade civil, apenas acreditando que o uso da função judiciária dará efetividade àquela, é um grave equívoco, que deve ser sanado.

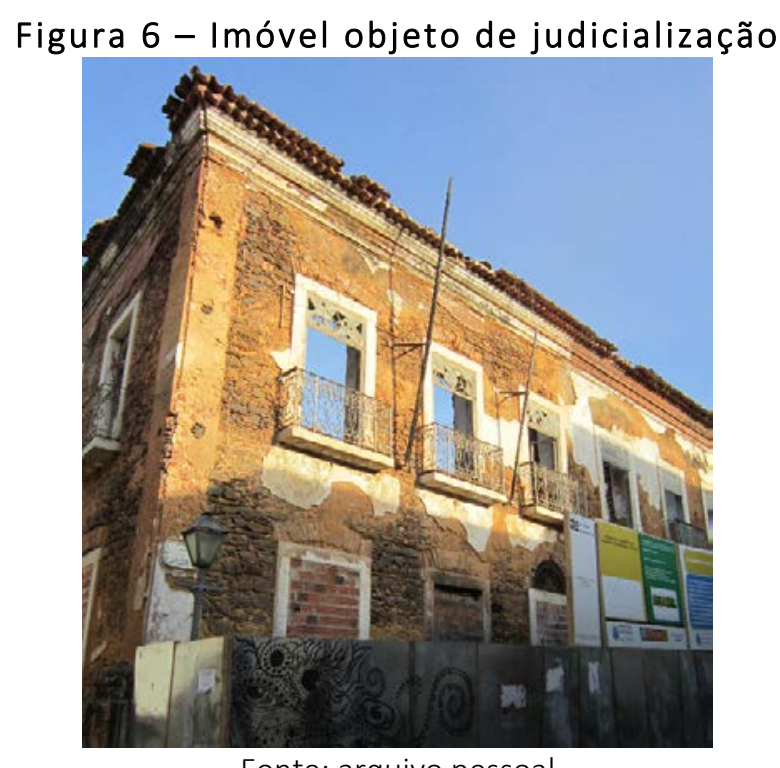

Fonte: arquivo pessoal

Qualquer ação pública, nesse sentido, deve ser precedida da formulação e implementação de fóruns que fomentem e permitam um diálogo consciente. E, caso as pretensões da sociedade civil ou dos agentes econômicos se mostrem equivocadas do ponto de vista patrimonial, a tecnocracia deveria agir, através da educação patrimonial, por exemplo, esclarecendo os equívocos dessas pretensões desacertadas. Essa premissa, antes de enfraquecer as instituições democráticas, de forma contrária, acaba por fortalecê-las. Sobre as instituições Niklas Luhmann (1983, p. 84-85) adverte:

É exatamente a indeterminação, o anonimato, a imprevisibilidade e a incógnita de terceiros relevantes que garante a confiabilidade e a homogeneidade das instituições. Ela se baseia na neutralização de todas as referências que levam a que determinados terceiros possam ter outras expectativas que as esperadas.

As instituições se fundamentam, então não na concordância fática de determináveis manifestações de opiniões, mas sim no sucesso ao superestimá-las. Sua continuidade está garantida enquanto quase todos suponham que quase todos concordem; e possivelmente até mesmo enquanto quase todos concordem. Daí surge, comparativamente ao consenso fático, uma maior estabilidade e uma mais apurada sensibilidade. Constituídas sobre areia movediça da experiência concreta, através de mecanismos de seleção, as instituições podem tornar-se amplamente independentes da distribuição fática das experiências reais com respeito a temas e momentos, e também das entradas e saídas de seus participantes, 
passando então a moldar elas mesmas a estrutura de expectativas desses processos. Ao nível das expectativas sobre expectativas de terceiros, elas atingem um grau tão característico de sedimentação, ao ponto de não mais tolerarem um recurso à realidade concreta das opiniões e do comportamento. A certeza de suas expectativas se baseia na assimilação de hipóteses improvisadas que não foram oportunamente refutadas, no descobrimento de suas implicações e de outras possibilidades, no manter latente a maior parte dos desvios e todas comunicações que sinalizem expectativas divergentes e que possam dar-lhes ressonância social - mas principalmente na dilação das chances fáticas do consenso.

A mensuração do nível de estabilidade das instituições deve partir exatamente da capacidade de independência dos indivíduos em relação a elas; instituições devem ser fortes não porque são constantemente requisitadas, mas porque suas regras são respeitadas, não sendo necessário que se manifestem explicitamente. E esse fortalecimento decorre do nível de esclarecimento que a sociedade civil tem de seus direitos e do nível de participação em relação aos seus deveres, isto é, de cuidar de um patrimônio coletivo, no caso.

Nesse sentido, não se desconhece ou se menospreza a relevância que as Instituições do Sistema de Justiça possuem para contribuir com o processo de desenvolvimento, pois as garantias decorrentes do arcabouço normativo do direito não bastam para que os cidadãos alcancem o bemestar pretendido; há a necessidade de atuação de outros agentes, sejam públicos ou privados, atuando mutuamente, na promoção do desenvolvimento; as instituições emergem nesse cenário porque têm papel relevante, mas é preciso que sejam eficientes e suas ações tenham por objetivo central o desenvolvimento entendido como um processo conjunto, em que atuam cidadãos, sociedade civil e instituições (SOUSA, 2011).

Dessa maneira, é essencial que as propostas de desenvolvimento cultural, dentre as quais se incluem as políticas patrimoniais, estejam alicerçadas em um eficiente sistema judiciário e de governo, que devem estar prontos para promover a segurança dos indivíduos e para garantir o bom funcionamento de instituições que promovam o desenvolvimento da sociedade (SOUSA, 2011), sujeitando-se ainda ao controle, prévio, concomitante e a posteriori, de sua eficiência. Porém, igualmente, é fundamental que a sociedade civil esteja apta e consciente do seu papel e das instituições, que não devem ser meros censores daquela.

Caso as políticas públicas culturais sejam implementadas com forte respaldo público e orientadas para amplos setores desfavorecidos, a cultura se constituirá em um caminho para a inclusão, reforçando outros caminhos; a cultura, ainda, é relevante porque restitui a autoestima a grupos marginalizados, bem como pode desempenhar papel importante na reconstituição de laços de associatividade, pois a mera ideia de cultura já implica em ação coletiva (SEN; KLIKSBERG, 2010). 
A política patrimonial deve ser capaz de fomentar a capacitação das pessoas, que têm um papel na ética social (SEN, 2011) para que estas possam se emancipar e que não se tornem dependentes apenas da atuação de instituições, inclusive daquelas do Sistema de Justiça.

Desconsiderar a sociedade civil é uma maneira de desacreditar na emancipação humana, é desacreditar que o homem é capaz de agir politicamente, ser dotado de consciência, que pode ser fomentada. Portanto, uma política patrimonial eficiente sugere a conscientização da sociedade civil, ou seja, uma ação cultural para a liberdade, o que pressupõe a comunhão entre os líderes, sejam eles políticos ou tecnocratas, e as massas populares, sociedade civil, como sujeitos da transformação da realidade, com indivíduos conscientes, capazes de perceber, de conhecer, de recriar e conscientes de si mesmos (FREIRE, 1987).

Os conflitos são inerentes em qualquer convívio social. Contudo, não se pode devotar um monopólio para a resolução de todos os conflitos, tratando-se a sociedade civil como ser fosse órfã (MAUS, 2000) e sem capacidade de diálogo e consenso.

Para que se modifique o quadro de dissociação entre a prescrição da legislação e a realidade social, não basta mudar o direito substantivo e o direito processual; são necessárias outras mudanças, uma revolução democrática da justiça que pressuponha mudanças comportamentais e de visão do direito, com uma nova cultura jurídica e judiciária (SANTOS, 2007).

Nesse sentido, o trabalho, não desconhece ou se menospreza a relevância que as Instituições do Sistema de Justiça possuem para contribuir com o processo de desenvolvimento, pois as garantias decorrentes do arcabouço normativo do direito não bastam para que os cidadãos alcancem o bem-estar pretendido; há a necessidade de atuação de outros agentes, sejam públicos ou privados, atuando mutuamente, na promoção do desenvolvimento; as instituições emergem nesse cenário porque têm papel relevante, mas é preciso que sejam eficientes e suas ações tenham por objetivo central o desenvolvimento entendido como um processo conjunto, em que atuam cidadãos, sociedade civil e instituições (SOUSA, 2011).

Assim, a busca por caminhos fáceis, que desconsideram a real problemática do Centro Histórico de São Luís, pouco contribui para se dar efetividade à tutela de um patrimônio cultural que, além de pertencer à humanidade, deve ser capaz de fomentar o espírito de pertencimento àqueles que nele continuam a ser negligenciados, como se fossem meros figurantes de um espetáculo burocrático e processual, enfadonho e fora da realidade. 


\section{CONSIDERAÇÕES FINAIS}

O trabalho analisou a judicialização das políticas públicas que tratam do Centro Histórico de São Luís, especialmente as que dizem respeito à Zona de Tombamento Federal, questionandose a real efetividade de tal processo de delegação de atribuições que passam alheias a quaisquer discussões com a sociedade civil interessada.

Sem querer ser exauriente, mas apenas informar o que parece mais evidente, a partir da análise dos processos judiciais, apresentam-se 03 (três) equívocos em torno das políticas patrimoniais aplicadas ao Centro Histórico de São Luís, a saber: a) a desconsideração do fator pobreza; b) a falta de estímulos à diversidade urbana; c) e a falta de diálogo com a sociedade civil.

Esses três fatores, desconsiderados pelas políticas de proteção ao Centro Histórico de São Luís, impedem o sucesso da política patrimonial, levando-se a uma judicialização que, também, não consegue dar respostas efetivas.

Portanto, pela análise dos dados apresentados, foi possível notar uma forte desarticulação entre sociedade civil e Estado, o que parece levar a um desacerto das políticas patrimoniais, incapazes de proporcional o direito ao desenvolvimento cultural de forma efetiva para as populações interessadas.

Da falta de participação da sociedade civil, cria-se um vácuo entre aquilo que é pensado pela tecnocracia patrimonial e a vivência daqueles que usufruirão do Centro Histórico, que, aos poucos, vem se tornando apenas como espécie de estorvo patrimonial, habitado pelas classes menos favorecidas economicamente' enquanto, inclusive, a Administração Pública, em diversos níveis, trata de abandoná-lo em fuga para outras áreas da cidade.

Assim, a pesquisa não desmerece a função judiciária ao tratar da tutela do patrimônio cultural da cidade de São Luís, mas, através de dados empíricos, questiona a crescente judicialização e a delegação excessiva do campo decisório que deveria estar repartido de forma equânime entre as outras funções estatais, assim como em relação à sociedade civil, que não pode ter sua relevância negligenciada, sob pena de se enfraquecer um regime democrático que está em processo de consolidação.

Dessa forma, o trabalho alerta que não será o Judiciário quem resolverá a questão patrimonial no Centro Histórico de São Luís, devendo haver maior participação da sociedade civil, através de estímulos proporcionados pelas políticas públicas. 


\section{REFERÊNCIAS BIBLIOGRÁFICAS}

ARANTES, Otília. Urbanismo em fim de linha e outros estudos sobre o colapso da modernização arquitetônica. 2. ed. São Paulo: Editora da Universidade de São Paulo, 2001.

CARNELUTTI, Francesco. Como se faz um processo. Tradução de Ricardo Rodrigues Gama. Campinas: Russel Editores, 2009.

CHAUÍ, Marilena. Cultura e democracia: o discurso competente e outras falas. 13. ed. São Paulo: Cortez, 2011.

CORRÊA, Alexandre Fernandes. Vilas, parques, bairros e terreiros: novos patrimônios na cena das políticas culturais de São Paulo e São Luís. São Luís: EDUFMA, 2003.

FLICK, Uwe. Uma introdução à pesquisa qualitativa. Tradução de Joice Elias Costa. 3. ed. Porto Alegre: Artmed, 2009.

FREIRE, Paulo. Ação cultural para a liberdade e outros escritos. 8. ed. Rio de Janeiro: Paz e Terra, 1987.

FUNARI, Pedro Paulo Abreu; PELEGRINI, Sandra de Cássia Araújo. Patrimônio histórico e cultural. Rio de Janeiro: Zahar, 2006.

HABERMAS, Jürgen. Direito e democracia: entre facticidade e validade. Volume I. Tradução de Flávio Beno Siebeneichler. 2. ed. Rio de Janeiro: Tempo Brasileiro, 2003.

Teoria e práxis: estudos de filosofia social. Tradução e apresentação de Rúrion Melo. São Paulo: Editora UNESP, 2013.

Mudança estrutural da esfera pública: investigações sobre uma categoria da sociedade burguesa. Tradução de Denílson Luís Werle. São Paulo: Editora UNESP, 2014.

HALL, Peter. Cidades do amanhã: uma história intelectual do planejamento e do projeto urbanos no século XX. Tradução de Pérola de Carvalho. São Paulo: Perspectiva, 2009.

HARVEY, David. Condição pós-moderna: uma pesquisa sobre origens da mudança cultural. Tradução de Adail Ubirajara Sobral e Maria Estela Gonçalves. 4. ed. São Paulo: Edições Loyola, 1994.

JACOBS, Jane. Morte e vida de grandes cidades. Tradução de Carlos S. Mendes Rosa. São Paulo: Martins Fontes, 2000.

LACROIX, Maria de Lourdes Lauande. São Luís do Maranhão: corpo e alma. São Luís, 2012.

LASSALE, Ferdinand. A essência da Constituição. Tradução de Walter Stoner. 6. ed. Rio de Janeiro: Lumen Juris, 2001.

LEFEBVRE, Henry. O direito à cidade. Tradução de Rubens Eduardo Frias. São Paulo: Centauro, 2001. 
LE GOFF, Jacques. Por amor às cidades: conversações com Jean Lebrun. Tradução de Reginaldo Carmello Corrêa de Moraes. São Paulo: Editora da UNESP, 1998.

LEITE, Rogério Proença. Contra-usos da cidade: lugares e espaço público na experiência urbana contemporânea. Campinas/Aracaju: Editora da UNICAMP/Editora UFS, 2004.

LOPES, José Antonio Viana (org.). São Luís, Ilha do Maranhão e Alcântara: Guia de Arquitetura e Paisagem. Ed. Bilíngue. Sevilla: Consejería de Obras Públicas y Transportes, Dirección General de Arquitectura y Vivienda, 2008.

LOURÉS SEOANE, María Luisa. Del concepto de "monumento histórico" al de "patrimonio cultural". Ciencias Sociales: Revista de la Universidad de Costa Rica, vol. I, n. 94, p. 141-150, 2001.

LUHMANN, Niklas. Sociologia do Direito I. Tradução de Gustavo Bayer. Rio de Janeiro: Tempo Brasileiro, 1983.

MAUS, Ingeborg. Judiciário como superego da sociedade: o papel da atividade jurisprudencial na sociedade "órfã". In: Novos Estudos, Tradução de Martonio Lima e Paulo Albuquerque, São Paulo, CEBRAP, no 58, nov. 2000.

MUMFORD, Lewis. A cidade na história: suas origens, transformações e perspectivas. Tradução de Neil R. da Silva. 4. ed. São Paulo: Martins Fontes, 1998.

PASUKANIS, Eugeny Bronislanovich. A teoria geral do direito e o marxismo. Tradução de Paulo Bessa. Rio de Janeiro: Renovar, 1989.

PEREIRA, Paulo Fernando Soares. Os autos que crescem e o patrimônio que padece: a tutela do patrimônio cultural imobiliário na Cidade de São Luís e as Instituições do Sistema de Justiça Federal. Dissertação. (Mestrado). Universidade Federal do Maranhão - UFMA, Programa de PósGraduação em Direito e Instituições do Sistema de Justiça, 2014, 216 p.

SANTOS, Boaventura de Sousa. Para uma revolução democrática da Justiça. 3. ed. São Paulo: Cortez Editora, 2007.

SEN, Amartya; KLIKSBERG, Bernardo. As pessoas em primeiro lugar: a ética do desenvolvimento e os problemas do mundo globalizado. Tradução de Bernardo Ajzemberg e Carlos Eduardo Lins da Silva. São Paulo: Companhia das Letras, 2010.

SEN, Amartya. A ideia de justiça. Tradução de Denise Bottmann e Ricardo Doninelli Mendes. São Paulo: Companhia das Letras, 2011.

SILVA, José Afonso da. Ação popular constitucional: doutrina e processo. 2. ed. São Paulo: Malheiros, 2007.

SOARES, Inês Virgínia Prado. Direito ao (do) patrimônio cultural brasileiro. Belo Horizonte: Fórum, 2009. 
SOUSA, Monica Teresa Costa. A importância das instituições de justiça para a afirmação do direito ao desenvolvimento. Revista do Curso de Direito. São Luís: UFMA, v. 1, n. 1. jan./jun., p. 141-158, 2011.

VIANA, Luiz Werneck et al. A judicialização da política e das relações sociais no Brasil. Rio de Janeiro: Revan, 1999.

WALDRON, Jeremy. A dignidade da legislação. Tradução de Luís Carlos Borges. São Paulo: Martins Fontes, 2003.

Trabalho enviado em 13 de junho de 2016.

Aceito em 11 de agosto de 2016. 